\title{
A SURVEY ON TEACHING SPEAKING PERCEPTION EFL LEARNERS' FLUENCY (A CASE STUDY AT IAIN SYEKH NURJATI CIREBON
}

\section{Siti Nurhasanah}

e-mail: sitynurhasanah.one@gmail.com

\begin{abstract}
Every human being in the world needs speaking to express their ideas, their feelings and to gain the information. Speaking therefore is very important. Many problems of speaking are faced by EFL Learners of IAIN Syekh Nurjati Cirebon. This research was primarily intended to capture the learners' speaking fluency level in IAIN Syekh Nurjati Cirebon: the lesson plan reflect the teaching of speaking fluency, how lecturers perceive the concept of speaking fluency, and how the learners' monitor their speaking fluency. The investigation itself was centered on the conception of the principle of teaching EFL Speaking. To investigate lecturers' perception of the teaching EFL speaking, the researcher conducted an in-depth interview to speaking and conversation 1 until 5 lecturers. The researcher also analyzed speaking lesson plan as a representation towards lecturers' orientation in teaching speaking process and also to investigate the level of speaking used by lecturers in teaching speaking and conversation. The researcher also used questionnaire and speaking test as tools to collect data. The analysis process is designed by interpreting the data through transcriptions and analysis. The percentage merely was used to analyze for obtaining descriptive statistics from data collected by in-depth interview and questionnaire. Data from speaking test and document were interpreted and reviewed to get understanding from data collected. The main conclusion of this research are each lecturer has different levels in the learning speaking process and speaking fluency levels determined by lecturer strategies in learning process.
\end{abstract}

Key words: Teaching EFL Speaking, Fluency Levels, Lesson Plan, EFL Learners. 


\section{BACKGROUND}

Speaking skill, especially speaking fluency not only thought in junior high school or senior high school but also tought in university. Because according to Rebecca Hughes (2011:23) state that fluency is the aspect of speaking is taught to second language or foreign language learners is not for the native speaking. It means that British learners who only learn English as long as 1 years will more fluent than Indonesian learners who learn Englishas long as 4 years.

All of the learners English Education Department at IAIN Syekh Nurjati Cirebon as English Foreign Language (EFL) learners and they still have to learn speaking fluency. So that, the researcher conduct the project to investigates the learners speakig fluency levels. The researcher using fluency levels from Simesen (2010:8). To investigate speaking fluency level of the learners, researcher also analyzed lesson plan that has been created by each lecturer to explore the orientation of lecturer in teaching speaking and the level which they use in the classroom.

Spoken fluency, is actually exclusively devoted to the concept in speaking. It has six levels and includes detailed characterizations of language typical for each level. As may be noticed in the scale, quoted below, characterizations such as 'unhesitating flow', 'spontaneity' and 'few noticeably long pauses' are used as positive features of language at upper proficiency levels $(\mathrm{C} 2, \mathrm{C} 1$ and $\mathrm{B} 2)$, while the opposite, including 'noticeable hesitation', 'false starts' and 'much pausing', are used about language at lower proficiency levels (B1, A2 and A1) (Simensen, 2010:8). From disucussion above, the researcher conduct the study that investigated level of English Foreign Learners' (EFL) ability on speaking fluency. This study also will analyze philosophy of teaching English speaking lecturers and direction on teaching speaking English. The investigation itself was focused on the speaking fluency of thel earners' at Departement of English Education IAIN Syekh Nurjati Cirebon.

The researcher found the problem about speaking skill at EFL Learners' IAIN syekh Nurjati Cirebon. The important of this research is to solve the problem on Speaking Fluency and Teachig Percepion on IAIN Syekh Nurjati Cirebon.

In this research, fluency has a relationship that is closely associated with pragmatic competence and strategic competence. The model presented below, from the same year, places the concept 'fluency' in a separate box, thus giving it an exceptional prominence. The idea is that components of knowledge of various kinds have to go tthrough the box 'fluency' to become performance or language in use (Færch, Haastrup and Phillipson 1984:69). By introducing a strategic competence component this model, together with similar models of communicative competence, take into account factors beyond linguistic knowledge that are necessary for language proficiency.

To be more specific, it tries to find information concerning the development of the lesson plan from the components that construct it, they are the competence standards, basic competences, and indicators of the lesson plans, the learning objectives, the instructional materials, the teaching and learning methods, the learning stages, the material/ learning resources, and the assessment of the lesson plans. Through analyze the lesson plan, the researcher will investigate the teacher 
orientation in teaching speaking. Based on journal title Analysis on The Lesson Plan of English Speaking Class Based on School-Based Curriculum (SBC) at Public Senior High Schools in Malang by Prajas (2009) who analyze five lesson plan from some senior high school in Malang gave the result, From the finding, there are only two lesson plans whose grades are seventies, they are LP 1 and LP 5, which mean that the lesson plans are categorized good. LP 1 belongs to the lower grade because it the basic competences are not developed appropriately based on the content standard, it has material/learning resources which are not written operationally, and it develops the assessment not quite well. Then, LP 5 belongs to the lower grade among the other lesson plans because in this lesson plan the teacher does not develop learning objectives inside, and he does not develop the assessment correctly. The other four lesson plans are categorized "very good.

Lesson plan is something important, that's why teachers need to realize this. They need to know and comprehend this curriculum well, so that they know what to do in conducting teaching instruction, including how to make lesson plan according to the curriculum. Teachers must be able to elaborate, define, and map the competence standards and basic competences given and determined by the government, and to apply those concepts in class through the lesson plan (Prajas, 2009).

Prajas (2009) said that It is found also that in general most of the lesson plans have the assessment component not quite well. The teachers still find it difficult to develop techniques of assessment which are in accordance with the instrument, and also the rubrics. Most of them also do not develop the material/learning resources operationally. In order to have good or very good lesson plans, there are some criteria which must be fulfilled. These criteria refer to each components of the lesson plan which construct the lesson plan itself. There are seven components of a lesson plan, they are (1) competence standards, basic competences, and indicators, (2) learning objectives, (3) instructional material, (4) teaching and learning method, (5) learning stages, (6) material/learning resource, and (7) assessment of the lesson plan.

To get balance result, before teaching in the classroom the teacher should make a lesson plan as a teaching guide. Because through construct the lesson plans, learning process has clear objectives. As a prajas (2009) state that the teaching and learning methods used in the lesson plan have to reflect the basic competences. Then, the learning stages have to be appropriate with the method. They have to be also students-cantered, give the students opportunities to interact with their friends or surrounding environments, and emphasize on the problem solving. About the material/learning resources of the lesson plan, they have to have good quality and current resources, and they are formulated operationally. The last, a good or very good lesson plan has to have assessment which is in line with the basic competence and learning indicators.

From the statement above, the researcher will conduct the research in speaking fluency area through analyzing the lesson plan. The researcher will provide matrix to make easy the researcher to know the outline of this research. The purpose of the matrix is to help you to think holistically about the research you are doing and that has been done (Alwasilah, 2014). 


\section{Meta theory}

Anne Lazaraton (2001:104) suggests that oral communication (speaking) is based on four dimensions or competences: grammatical competence (phonology, vocabulary, word and sentence formation), sociolinguistic competence (rules for interaction, social meanings), discourse competence (cohesion and how sentences are liked together); and strategic competence (compensatory strategies to use in difficult strategies). All of those factors connected each other. Rebecca Hughes (2011:5) suggest some concepts of speaking skill involves: speaking is not discrete skill, teaching speaking is not easily separated from other objective, teaching speaking vs using speaking to teach, insight from speech corpora, and bringing the facets of speaking together. Because of it, speaking has special role in educational field.

\section{Enlarging our view of fluency}

Fluency is defined in contrast to accuracy, which according to Richards et al (1985:109) "refers to the ability to produce grammatically correct sentences but may not include the ability to speak or write fluently". Traditionally, accuracy has been taught not only in grammar, as suggested by Richards et al, but also in vocabulary and pronunciation. Of course, grammar, vocabulary, and pronunciation would be included in the notion of grammar if Richards et al were using the all-inclusive notion of big "G" Grammar. However, I am fairly certain that is not what they meant, and will therefore have to come back to the issue of big "G" Grammar in the context of fluency teaching. In general, however, I feel that fluency can best be understood, not in contrast to accuracy but rather as a complement to it. As Brumfit (1984) phrased it, "In no sense is it [accuracy] meant to imply that fluent language may not also be accurate language."

The above definitions provide a fairly good starting point because they include different perspectives on fluency and describe much of what fluency is. In my view, however, a full explanation of fluency must account for many other factorsfactors that will be explored in this paper. The concept 'fluency', including the variant 'fluent', is often being used to characterize high language proficiency. It is most often used about skills in a foreign or second language, not in a mother tongue. Although the discussion in the present article is relevant for the teaching of most foreign languages, I will focus on English. Several perceptions of the concept 'fluency' exist. Two major types will be focused on here. The first is restricted to pointing out a number of typical and in general positive features in fluent language performance, such as smooth, rapid, effortless use of language (Crystal 1987:421).

Fluency is regarded as natural language use (Brumfit 1984:56). It means that language is spoken easily and without many pauses (Cambridge International Dictionary of English 1995:87). Naturally, these are features, which also are represented in studies of the concept over the last decades, to be returned to below.

My classroom experiences promoting fluency in my students have convinced me that we can only help our students become fluent after we have enlarged and restructured our view of the components of language and our concept of what fluency means. In 
more detail (see Table 1), before students can ever have any chance at improving their fluency, teachers must expand their traditional boundaries of accuracy to offer rules of appropriate including knowledge of the communicative language tools students must be able to use, the communicative language choices they should be able to make, and the communicative language strategies they must use to compensate for the fact that they, like all users of the language including native speakers, lack $100 \%$ knowledge of the language (Brown, 2003:3).

\section{METHOD}

Research method of this study is case study. (Ary, et al., 2010: 29) A case study is a type of ethnographic research study that focuses on a single unit, such as one individual, one group, one organization, or one program. The goal is to arrive at a detailed description and understanding of the entity (the "case"). In addition, a case study can result in data from which generalizations to theory are possible.

The study will be qualitative because the researcher takes a case study research. To accomplish this research, the researcher will take place at IAIN Syekh Nurjati Cirebon on Departement of English Education. The researcher takes IAIN Syekh Nurjai Cirebon as the place to accomplish this research.

This research is intended to explore learners' speaking fluency. To understand the phenomena, the researcher purposefully selects individual or group and site. Creswell (2009) states that the term used for qualitative sampling is purpose sampling. The researcher selects respondents to gained the information. To gained all information about speaking course in the first semester until fifth semester, the researcher invite all lecturers in speaking course as respondents. From 4 respondents in speaking course, only three respondents who followed up the invitations while one respondent refused. While all lecturers of Speaking and Conversation course were included to in depth interview, sample 55 students were chosen out of a population of 550 students. To determine sample the researcher take the theory from Arikunto (2002: 112) who states that "if the subject is less than 100, it is better taken all so research study population. If the subject is greater may be taken between $10-15 \%$ or 20-25\%."

The objective of the research is to investigate EFL Learners' Speaking fluency and teaching perception speaking fluency.

The researcher will focus on the analyzing the lesson plan to know the teacher's orientation in teaching speaking on fluency aspect also to know the philosophy of teaching speaking especially on fluency aspect. Through conduct analyze lesson plan the researcher also will investigate the learners' ability on speaking fluency. The researcher also conduct interview and make questionnaire to collecting data.

The researcher will get data from speaking course lesson plan, the lecturers of speaking course as the respondents and the learners of English Education Department at IAIN Syekh Nurjati Cirebon that located in Perjuangan street- Majasem, Cirebon. 


\section{Design}

The research is qualitative research. According to Lodico et al (2010: 142) that Qualitative research focus on the study of social phenomena and giving voice to the feelings and perceptions of the participants under study. As stated by Moleong (2007: 6) qualitative research is research subjects, such as behaviour, perception, motivation, action, etc., and qualitative research produces descriptive data in the form of words in a natural specific context by utilizing a variety of scientific methods.

This research takes place and time start on Mei until July, so this research takes time about 10 weeks. For the first week the researcher takes to do the phenomena of this research, and then the second weeks the researcher takes collecting the theoretical foundation and the next weeks the researcher is analysis the phenomena and takes the data analysis.

Table 1.12.1

Research Timeline

\begin{tabular}{|c|c|c|c|c|c|c|c|c|c|c|c|c|c|}
\hline \multirow{2}{*}{ No. } & \multirow{2}{*}{ Activities } & \multicolumn{4}{|c|}{ Mei } & \multicolumn{4}{|c|}{ June } & \multicolumn{4}{|c|}{ July } \\
\hline & & 1 & 2 & 3 & 4 & 1 & 2 & 3 & 4 & 1 & 2 & 3 & 4 \\
\hline 1. & $\begin{array}{l}\text { Writing } \\
\text { proposal } \\
\text { and } \\
\text { consultation }\end{array}$ & & & & & & & & & & & & \\
\hline 2. & $\begin{array}{l}\text { Conducting } \\
\text { Research } \\
\text { sample, } \\
\text { validity, and } \\
\text { reliability of } \\
\text { data }\end{array}$ & & & & & & & & & & & & \\
\hline 3. & $\begin{array}{l}\text { Collecting } \\
\text { of Data }\end{array}$ & & & & & & & & & & & & \\
\hline 4. & $\begin{array}{l}\text { Data } \\
\text { Analysis }\end{array}$ & & & & & & & & & & & & \\
\hline 5. & $\begin{array}{l}\text { Finishing } \\
\text { thesis } \\
\text { writing }\end{array}$ & & & & & & & & & & & & \\
\hline 6. & $\begin{array}{l}\text { Thesis } \\
\text { Examination }\end{array}$ & & & & & & & & & & & & \\
\hline 7. & $\begin{array}{l}\text { Thesis } \\
\text { Revision }\end{array}$ & & & & & & & & & & & & \\
\hline
\end{tabular}

Since the objective of this research is to explore EFL Learners' speaking fluency, the researcher consideres to select the source and type of data for the research. the resource come from the lesson plan of speaking course from semester 1 
until 5, lecturers speaking course and the learners' in English Education IAIN Syekh Nurjati Cirebon.

While, all lecturers of EFL speaking course were included to interview, samples 55 students were chosen out of a population of 550 students. The learners also should conduct the speaking test that recorded and then the researcher write the result into transcription.

The instrument of this research is have purpose to get the relevant and real data, the researcher should provide some instrument. In this research, the researcher use: Lesson plan analysis, tables of interview and tables of questionnaire.

\section{In-depth Interview}

An In-depth Interview survey, however, is a form on which the researcher records answers supplied by the participant in the study. The researcher asks a question from an interview guide, listens for answers or observes behavior, and records responses on the survey (Creswell, 2012:382). An interview is a "conversation with a purpose" (Rossman \& Tallis, cited in Chambliss \& Schutt, 2003:177) conducted with a person or a group of persons in some organisation.

Once you decide to collect qualitative interviews, you next consider what form of interviewing will best help you understand the central phenomenon and answer the questions in your study (Creswell, 2012). Interviews involve some form of direct contact between the people in the sample group and the interviewer (the researcher or someone trained by the researcher), who presents the questions to each person in the sample group and records their responses. (Ary, et al., 2010: 379).

In the depth interview process, the researcher has prepared core questions for the all respondents who consists of lecturers speaking course in the first semester until fifth semester. From four respondents, one of respondents refused the invitation. So that, the researcher only conducted in the depth interview towards three respondents.

\section{Questionnaire}

The direct one-on-one contact with subjects in a personal interview is timeconsuming and expensive. Often, much of the same information can be obtained by means of a questionnaire mailed to each individual in the sample, with a request that he or she complete and return it by a given date. Because the questionnaire is mailed, it is possible to include a larger number of subjects as well as subjects in more diverse locations than is practical with the interview. (Ary, et al., 2010: 384).

Based on official administration, the number of students in English Education Department IAIN Syekh Nurjati Cirebon are 550 students. Arikunto (2006:112) states that population out of 100 participants is only need $10 \%$ to be taken as data collection. Te researcher used purposive sampling.

The researcher truly followed the technique of analysis data Lodico et.al (2006:301) suggest in the way how to analyze the data. The step conducted as follows: 
1) The researcher prepared and organized the data collected from interview, questionnaire, observation and test. Recorded data from interview and test will fully transcriptions. The frequency and percentage will be used to analyze in order to obtain descriptive statistics from data collected by interviewing and questionnaire. While data observation and document were organized to get sense of what are in the data.

2) The researcher read and reviewed initially to get understanding from all data collected whether enough to be investigated.

3) Then the researcher clasified the data into coding in several categories to avoid losing the data or incompatible data according to the respondents' experience.

4) The researcher interpreted the report the data findings as a conclusion in the end of this qualitative research.

\section{FINDING And DISCUSSION}

\section{First Chapter}

In the first chapter the researcher presented how the lesson plan reflect the teaching of speaking fluency. To measure learners' speaking fluency, the researcher not only takes the data from interview and questionnaire but also from lesson plan analysis. The discussion of this chapter is divided into fluency levels in the lesson plan by \#R1, fluency levels in the lesson plan by \#R2 and fluency levels in the lesson plan by \#R3. This chapter answered the first research question how the lesson plan reflect the teaching of speaking fluency. The researcher investigates five lesson plan of speaking course. The data represent speaking fluency levels which determined from lesson plan analysis.

The researcher conducted lesson plan analysis to know completeness the components of lesson plan of speaking course. To know lesson plan completeness the researcher use eleven characteristics, such as: works towards appropriate goals, requires the use of higher-order thinking skills and new literacy's, integrates the learning goals, includes a variety of resources, engages all students actively in authentic tasks, uses technology effectively, efficiently, and as a learning tool. Lesson plan analysis conducted to know the objectives of the lecturers towards learning process on speaking course. As Chatel (2002:3) said that a lesson plan is a rehearsal for delivering effective instruction in that it provides the teacher the opportunity to anticipate instructional and learning needs and make plans to address them before stepping if front of the students. Lesson planning includes but is not limited to selecting content, organizing content, selecting assessments, and determining pedagogy (Danielson, 2007:45; Popham, 2011).

The result of discussion above about material in the lesson plan first semester until fifth semester are: in the first semester lecturer \#R1 use $80 \%$ basic levels and $20 \%$ intermediate levels in the teaching process. In the second semester lecturer \#R2 in the class (A,B) use 70\% Basic Level and 30\% intemediate level. While \#R2 in the second semester class (C,D) use $90 \%$ basic level and 10\% intermediate level. \#R3 in the fourth and fifth semester has different level. In the fourth semester use $60 \%$ 
intermediate and $40 \%$ proficient level. In the fifth semester use $20 \%$ intermediate $80 \%$ proficient level.

\section{Second Chapter}

In the second chapter the researcher discussed about lecturers perceive the concept of speaking fluency. the discussion in this chater divide into three sections which identify lecturers' personal background, lecturers beliefs on teaching speaking fluency, prefered approach and strategy to teach EFL speaking fluency. this chapter answered the second research question. The data was taken from in-depth interview and questionnaire. The data represents lecturers' perception in concept of speaking fluency.

The researcher was sent four invitation to lecturers' speaking and conversation from first semeter until fifth semester. The researchers invited the lecturer as aperticipants or respondents. The first invitation was sent via short message mobile phone. From four respondents, only three respondents who reply the the invitation while one of them no reply. The second invitation via the letter agreement to be a respondent. There were a total of women 0 and 3 men respondents $(100 \%)$ men with an average (33.33\%) are 20-30 years old and (66.67\%) are $31-40$ years old.

Lecturers' Personal background is very important. Because teacher has the main role in the teaching and learning process. In the teaching and learning process lecturers should be understood the material. Especially in the teaching speaking. To teach speaking class, lecturers should know how teach speaking skill and how to practice speaking in the daily life.

Lecturers personal background consists of: the age of lecturers and lecturers teaching experience. The researcher conduct the project only with three respondents and they are also as lecturers in the speaking and conversation course from first semester until five semester.

The result are \#R1 claimed that he emphasize pronunciation to develop learners' speaking fluency. Because the accurate pronunciation make the learners easy to deliver some information to other people.

According to Brown (2003:4) said that pronunciation here, the foreign language speak with pronounce some vocabulary native like. Because spoken English is very different from written English. For example: native speaker said "duyuwannagonnagedouda here?" [do you want to get out of here?]. From the example above, we can see spoken language and written language have very different form.

While (\#R2) emphasize on the pronunciation and pragmatics. Pragmatics is important to the learners to develop speaking fluency. If the lecturer emphasize on pragmatics aspect, he teach the learners not only fluency on speaking skill but also fluency in the particular context and social situation.

According to Brown (2003:4) Pragmatics includes those facets of language that are directly related to the particular contexts and social situations in which the language is being used. In other words, pragmatics encompasses the relationships between real world knowledge (especially of social conventions) and the language being used in a specific context. 
And the last (\#R3) state that he emphasize in vocabulary and pragmatics. It is because if we want to speak fluency, we should have many vocabulary to easier the learners deliver their feelings in the right time, in the right situation and in the right conditions.

Those are the explanation about lecturers perceive the concept of speaking fluency. The result shows that lecturers believe thar speaking is speaking should be learned, learners requires regular practice, lecturers believe that vocabulary is the first step to enhance speaking fluency ability. Pronunciation, praagmatics and vocabulary are the elements that lecturers emphasized in teaching speaking to develop learners' fluency.

\section{Third Chapter}

The last chapter showed the learners' way to monitor their ability in speaking, especially speaking fluency. The researcher taken data from EFL Learners at IAIN Syekh Nurjati Cirebon. The participants were learners of English departement Education IAIN Syekh Nurjati Cirebon consists of second semester, fourth semester and sixth semester. The researcher taken 55 samples out of 550 populations and shared questionnaire with 9 questions and conduct speaking test to know their speaking ability in fluency.

Questionnaire talking about how the learners' way to moitor their speaking fluency and what kind of fluency guides for self-monitoring that they use. What kinds of strategy that used by the learners to monitor their speaking fluency. However, speaking is a skill that needs more exercise and should be applied in the daily life.

Questionnaire consist of two parts, the form of questionnaire part one are six questions multiple choice. Whether in the part two is essay, the learners should have to answer the question with their own perspective and their ability, because in this part the researcher asks the learners respondents about their difficuties in speaking, and about the learners' strategies to conduct self-monitoring on their speaking fluency.

Besides that, this chapter answers the third research question about how do EFL learners' monitor their speaking fluency. This chapter are divided into three sections: learners' achievement on speaking skill, learners' difficulties on speaking fluency and learners' strategies to monitor their speaking fluency.

Every section showed the result of learners respondents questionnaire and speaking test. A questionnaire is a form used in a survey design that participants in a study complete and return to the researcher. The participant chooses answers to questions and supplies basic personal or demographic information (Creswell, 2012 : 382). Speaking test to measure learners' level fluency.

The result shows that most of the learners do not conduct special treatment or strategy to enhance their speaking fluency, the learners admitted that less vocabularies is the most difficult factor in speaking skill and it make learners not confidence to speak up, and most of the learners also choose movie as an effective media that support to monitor their speaking fluency. 
This finding also suggest that learners should do some strategies to monitor their speaking fluency out of the speaking class. through conduct special strategies, the learners can substract their difficulties in speaking skill.

\section{CONCLUSION}

This study was conducted to investigate learners' speaking fluency levels at IAIN Syekh Nurjati Cirebon. How the lecturers reflected speaking fluency in speaking lesson plan, how the lecturers perceived concept of speaking fluency, and how the learners' strategies to monitor their speaking fluency are. As it has been stated in the aims of the research, this thesis is intended to explore EFL learners speaking fluency levels.

The findings state that lesson plan also has a role in determining the level of fluency speaking learners. From five lesson plans analyzed by the researcher, it appears that every lesson plan has different levels of fluency. A level of fluency lesson plan is presented in the table below.

\begin{tabular}{|l|c|c|c|}
\hline \multirow{2}{*}{ Lesson Plan } & \multicolumn{3}{|c|}{ Levels of Fluency } \\
\cline { 2 - 4 } & Basic Level & Intermediate Level & Proficient Level \\
\hline $1^{\text {sr }}$ Semester & $80 \%$ & $20 \%$ & - \\
\hline $2^{\text {nd }}$ Semester $(A, B)$ & $70 \%$ & $30 \%$ & - \\
\hline $2^{\text {nd }}$ Semester (C,D) & $90 \%$ & $10 \%$ & $60 \%$ \\
\hline $4^{\text {th }}$ Semester & - & $40 \%$ & $20 \%$ \\
\hline $5^{\text {th }}$ Semester & - & $80 \%$ & \\
\hline
\end{tabular}

From table above, it appears that each semester has different levels of fluency in speaking course. The lecturers, who teach in the upper semester, use the material of fluency for proficient levels.

This research also identified lecturers perceive about concept of speaking fluency. The result shows that lecturers believe thar speaking is speaking should be learned, learners requires regular practice, lecturers believe that vocabulary is the first step to enhance speaking fluency ability. Pronunciation, praagmatics and vocabulary are the elements that lecturers emphasized in teaching speaking to develop learners' fluency.

However to achieve complete levels of fluency in speaking, of course that the learners should have some strategies. The results are most of the learners do not conduct special strategiesto monitor their speaking fluency.

\section{SUGGESTION}

From the findings above, the following suggestion can be forwarded. It is necessary that the lecturers and curriculum should be integrated each other. This is aimed at developing learners' mastery in other course and especially in speaking fluency. 
Nurhasanah, A Survey on Teaching Speaking | 26

This finding also suggest that learners should do some strategies to monitor their speaking fluency out of the speaking class. through conduct special strategies, the learners can substract their difficulties in speaking skill. 


\section{REFERENCES}

Alwasilah, A. Chaedar. (2014). Pokoknya Studi Kasus: Pendekatan Kuallitatif, Bandung: PT Kiblat Buku Utama.

Ary, Donald., Jacobs , L. C., Sorenson, C \&Razavieh, A. 2010. Introduction to Research in Education 8th ed. USA : Wadsworth

AryKunto, Suharsimi. 2013. ProsedurPenelitianSuatuPendekatanPraktik. PT RinekaCipta: Jakarta.

Bailey, K. M. \& Savage, L. (Eds.). (1994). New ways in teaching speaking. Washington, DC: TESOL.

Barras. Robert. 2006. Speaking For Yourself. New York :Routledge.

Brown, Douglas H. 2000. Teaching by Principles an Interactive Approach to pedagogical $2^{\text {nd }}$ edition. California: Longman

Brown, J. D. (1996). Fluency development. In G. van Troyer (Ed.) JALT '95: Curriculum and evaluation (pp. 174-179). Tokyo: Japan Association for Language Teaching.

Brumfit, C. (1984). Communicative methodology in language teaching: The roles of fluency and accuracy. Cambridge: Cambridge University.

Byrne, Donn. 1976. Teaching Oral English, London: Longman.

Chatib, Munif. 2013. GurunyaManusia. Bandung: Kaifa Learning

Creswell, W John. 2012. Educational Research: Planning, Conducting and evaluating Quantitative and Qualitative Research $4^{\text {th }}$ edition. Boston USA: Pearson education, Inc

Danielson, C. (2007). Enhancing professional practice: A framework for teaching, 2nd ed. Alexandra, VA: ASCD

Fraenkel, R Jack \&Wallen, E Norman. 2009. How to Design and Evaluate Research in Education $7^{\text {th }}$ edition. New York: McGraw-Hill

Hughes, R. 2011. Teaching and Researching Speaking, 2nd edn. Edinburgh : Pearson Education Limited.

Kochhar, S .K (1985). Methods and Techniques of Teaching . Sterling Publishers.

Popham, W. J. (2011). Classroom assessment: What teachers need to know (6th ed.). Boston: Private Ltd. New Delhi.

Richards, C, Jack. 2011. Competencies and Performance in Language Teaching. Cambridge: Cambridge University Press

Richards. C Jack \& Schmidt, Richard. 2010. Language Teaching and Applied Linguistics Fourth Edition. Edinburgh: Pearson Education Limited. 